\title{
Using Enterobacter aerogenes DSM 30053 for Bio-hydrogen Production by Microbial Electrolysis Cells from Domestic Wastewater Aida H. Afify ${ }^{1}$; A. M. Abd EL Gwad ${ }^{2}$ and N. K. Abd EL Rahman ${ }^{2}$ \\ ${ }^{1}$ Microbiology Dept., Fac. Agric., Mansoura Univ., Mansoura, Egypt. \\ ${ }^{2}$ Soil Fertility and Microbiology Dept., Desert Res. Center, Matariya, Cairo, Egypt.
}

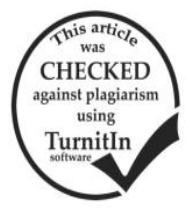

\section{ABSTRACT}

Microbial electrolysis cells (MECs) were used for production of bio-hydrogen $\left(\right.$ Bio- $\left.\mathrm{H}_{2}\right)$ by Enterobacter aerogenes DSM 30053 from domestic wastewater at three volumes of anode chamber in MECs $300 \mathrm{ml}, 400 \mathrm{ml}$ and $500 \mathrm{ml}$ were applied. Power supply of $0.4 \mathrm{~V}, 0.6 \mathrm{~V}$ and $0.8 \mathrm{~V}$ was used applied to MECs using a regulated external voltage. The highest volume of Bio- $\mathrm{H}_{2}$ $112.83 \mathrm{~cm}^{3}$ production was obtained from domestic wastewater without addition of bacteria at the anode chamber $500 \mathrm{ml}$ with power supply $0.8 \mathrm{~V}$. While the highest volume of Bio- $\mathrm{H}_{2} 316 \mathrm{~cm}^{3}$ production was obtained by Enterobacter aerogenes DSM 30053 at the anode chamber $500 \mathrm{ml}$ with power supply $0.4 \mathrm{~V}$ from domestic wastewater.

Keywords: Microbial electrolysis cells, Bio-hydrogen, Domestic wastewater, Enterobacter aerogenes DSM 30053.

\section{INTRODUCTION}

Domestic wastewater was used as substrate in microbial electrolysis cells at the anode chamber to produce bio-hydrogen in cathode chamber. Bacteria degraded organic matter in domestic wastewater into electrons and protons. The electrons were transferred by bacterial strains to the anode chamber which released to the cathode chamber through the circuit, protons pass to the cathode across membrane or salt bridge and combine with electrons in cathode chamber for production hydrogen. Montpart et al., (2015)

Enterobacter aerogenes is gram-negative and facultative anaerobic. It is live in various wastewater, $\mathrm{pH}$ 6-7 is optimum value of $\mathrm{pH}$ for bio-hydrogen production, which have the capability to transfer electrons from inside the cell to the extracellular acceptors through c-type cytochromes and microbial nanowires (flagella and pili) present on their outer membrane. Enterobacter aerogenes was form biofilm on the anode electrode in MECs and act as electron acceptors and transfer electrons to the anode from biocatalytic reactions in bio-electrochemical reactors. Kiran and Gaur (2013)

In this study domestic wastewater was used as substrate for $\mathrm{Bio}-\mathrm{H}_{2}$ production with and without bacteria. Enterobacter aerogenes DSM 30053 was used in MECs for degraded organic matter in domestic wastewater at anode chamber. Salt bridge was used as membrane in MEC. The effect of volume of anode chamber and power supply as the external voltage to the MECs on volume of bio-hydrogen gas.

\section{MATERIALS AND METHODS}

Bacteria used and preparation:

Nutrient broth medium (13gm / liter of distilled water) was used for preparation of bacterial culture, Enterobacter aerogenes DSM 30053 was obtained from microbiological resource center (MIRCEN), Faculty of Agriculture, Ain Shams University, Cairo, Egypt.

Substrate preparation:

Domestic wastewater were obtained from ELBerka wastewater treatment plant, EL-Khanka city, ELQaliubiya Governorate, Egypt. Drops of $1 \mathrm{M} \mathrm{HCl}$ acid was added to the substrate for adjusted $\mathrm{pH}$ to 7 and $0.2 \mathrm{M}$ sodium phosphate buffer solution .All analyzes of domestic wastewater were carried out in the Central Lab at the Desert Research Center(Abd El Rahman, 2017 ) . The characteristics of domestic wastewater used in the experiments are depicted in Table 1.

Table 1. The characteristics of domestic wastewater.

\begin{tabular}{lc}
\hline Test & Domestic wastewater \\
\hline $\mathrm{pH}$ & 7.4 \\
Color & Gray \\
Turbidity ( NTU ) & 75.8 \\
Electrical conductivity ( ms ) & 10.42 \\
Organic matter ( \% ) & 16.35 \\
Total dissolved solids ( mg / L ) & 3660 \\
Chemical oxygen demand ( mg / L ) & 243 \\
Biochemical oxygen demand (mg / L) & 552 \\
\hline
\end{tabular}

\section{MEC design and operation:}

Design of MEC consists of anode and cathode chambers separated by salt bridge (agar $20 \%+1 \mathrm{M}$ of Potassium Chloride) as membrane. Volume of each chamber has a $300 \mathrm{ml}, 400 \mathrm{ml}$ and $500 \mathrm{ml}$. Carbon brush (No.34 D) plate as anode electrode and stainless steel (304) as cathode electrode were connected to power supply. Anode chamber was filled with domestic wastewater $(300 \mathrm{ml}, 400 \mathrm{ml}$ and $500 \mathrm{ml})$ and $30 \mathrm{ml}, 40$ $\mathrm{ml}$ and $50 \mathrm{ml}(10 \% \mathrm{v} / \mathrm{v})$ of bacterial culture. Cathode chamber was filed by $300 \mathrm{ml}, 400 \mathrm{ml}$ and $500 \mathrm{ml}$ of distilled water. Copper wire connected between positive and negative electrodes of power supply $(0.4 \mathrm{~V}, 0.6 \mathrm{~V}$ and $0.8 \mathrm{~V} / 500 \mathrm{~mA} / \mathrm{DC} / 50 \mathrm{~Hz})$.

Volume of Bio-hydrogen $\left(\mathrm{Bio}-\mathrm{H}_{2} \mathrm{~cm}^{3}\right)$ :

Bio-hydrogen produced in cathode chamber was collected in burettes tubes by downward displacement of water. Ujwal et al., (2015)

Volume of Bio-H2 $(\mathrm{cm} 3)=$ length of burette reading (cm) $\times \pi \mathbf{r} 2(\mathbf{c m} 2)$

Where: $\pi=3.14, \quad \mathrm{r}=$ radius of burette tube Statistical analysis:

Statistical analysis of data was carried out according to (Statistix 9) for Windows using LSD test to compare between means values.

\section{RESULTS AND DISCUSSION}

Bio-hydrogen Production from domestic wastewater without bacteria:

Domestic wastewater were filled in anode chamber ( $300 \mathrm{ml}, 400 \mathrm{ml}$ and $500 \mathrm{ml}$ ) and distilled 
water in cathode chamber ( $300 \mathrm{ml}, 400 \mathrm{ml}$ and $500 \mathrm{ml}$ ) respectively. At the anode chamber $300 \mathrm{ml}$ hydrogen gas was produced in cathode chamber started from sixth day with power supply $0.6 \mathrm{~V}$ and $0.8 \mathrm{~V}$ and seventh day with power supply $0.4 \mathrm{~V}$. onwards till fifteenth day. Significant differences were found between the highest volume of Bio-H2 $54.64 \mathrm{~cm} 3$ with power supply $0.8 \mathrm{~V}$ and lowest volume of Bio-H2 $41.49 \mathrm{~cm} 3$ with power supply $0.4 \mathrm{~V}$. But no significant differences were found between the volume of Bio- $\mathrm{H} 254.64 \mathrm{~cm} 3$ and volume of Bio-H2 $52.11 \mathrm{~cm} 3$ with power supply $0.6 \mathrm{~V}$ (Table2).

The present results are in agreement with those reported by Jia et al., (2010) who investigated the biohydrogen can be produced using MECs as bioelectrochemical reactors with power supply over $0.4 \mathrm{~V}$ and bio-hydrogen gradually increased with increasing power supply.

Table 2. The anode chamber $300 \mathrm{ml}$ for $\mathrm{Bio}-\mathrm{H}_{2}\left(\mathrm{~cm}^{3}\right)$ production with power supply $(0.4 \mathrm{~V}, 0.6 \mathrm{~V}$ and $0.8 \mathrm{~V})$ in MECs from domestic wastewater without bacterial addition.

\begin{tabular}{|c|c|c|c|c|c|c|c|}
\hline \multirow[b]{2}{*}{ Days } & \multirow{2}{*}{$\begin{array}{l}\text { Power } \\
\text { supply }\end{array}$} & \multicolumn{2}{|c|}{$0.4 \mathrm{~V}$} & \multicolumn{2}{|c|}{$0.6 \mathrm{~V}$} & \multicolumn{2}{|c|}{$0.8 \mathrm{~V}$} \\
\hline & & $\begin{array}{c}\text { Burette reading } \\
(\mathrm{cm})\end{array}$ & $\begin{array}{l}\text { Volume of Bio- } \mathrm{H}_{2} \\
\text { collected }\left(\mathrm{cm}^{3}\right)\end{array}$ & $\begin{array}{c}\text { Burette reading } \\
(\mathrm{cm})\end{array}$ & $\begin{array}{l}\text { Volume of Bio-- } \mathrm{H}_{2} \\
\text { collected }\left(\mathrm{cm}^{3}\right)\end{array}$ & $\begin{array}{c}\text { Burette reading } \\
(\mathbf{c m})\end{array}$ & $\begin{array}{c}\text { Volume of Bio-H } \\
\text { collected }\left(\mathrm{cm}^{3}\right)\end{array}$ \\
\hline$\overline{1}$ & & 0 & 0.0 & 0 & 0.0 & 0 & 0.0 \\
\hline 2 & & 0 & 0.0 & 0 & 0.0 & 0 & 0.0 \\
\hline 3 & & 0 & 0.0 & 0 & 0.0 & 0 & 0.0 \\
\hline 4 & & 0 & 0.0 & 0 & 0.0 & 0 & 0.0 \\
\hline 5 & & 0 & 0.0 & 0 & 0.0 & 0 & 0.0 \\
\hline 6 & & 0 & 0.0 & 1.2 & 6.07 & 1.5 & 7.59 \\
\hline 7 & & 1.5 & 7.59 & 2.4 & 12.14 & 2.6 & 13.15 \\
\hline 8 & & 2.2 & 11.13 & 3.8 & 19.22 & 3.9 & 19.73 \\
\hline 9 & & 3.6 & 18.21 & 5.2 & 26.31 & 5.4 & 27.32 \\
\hline 10 & & 5.2 & 26.31 & 6.8 & 34.40 & 7 & 35.42 \\
\hline 11 & & 6.8 & 34.40 & 8.2 & 41.49 & 8.6 & 43.51 \\
\hline 12 & & 7.5 & 37.95 & 9.1 & 46.04 & 9.8 & 49.58 \\
\hline 13 & & 7.9 & 39.97 & 9.7 & 49.08 & 10.4 & 52.62 \\
\hline 14 & & 8.1 & 40.98 & 10.1 & 51.1 & 10.7 & 54.14 \\
\hline 15 & & 8.2 & 41.49 & 10.3 & 52.11 & 10.8 & 54.64 \\
\hline $\begin{array}{l}\mathrm{VH} \mathrm{H}_{2} \\
\mathrm{LSD}\end{array}$ & & 41 & & $\begin{array}{l}52 \\
3 .\end{array}$ & & & 64 \\
\hline
\end{tabular}

The hydrogen gas was started production from fourth day with power supply $0.6 \mathrm{~V}$ and $0.8 \mathrm{~V}$ at the anode chamber $400 \mathrm{ml}$ and fifth day with power supply $0.4 \mathrm{~V}$. No significant differences were found between the highest volume of $\mathrm{Bio}-\mathrm{H}_{2} 90.57 \mathrm{~cm}^{3}$ with power supply $0.8 \mathrm{~V}$ and volume of Bio- $\mathrm{H}_{2} 87.03 \mathrm{~cm}^{3}$ with power supply $0.6 \mathrm{~V}$. The lowest volume of $\mathrm{Bio}-\mathrm{H}_{2}$ $74.88 \mathrm{~cm}^{3}$ with power supply $0.4 \mathrm{~V}$ was significantly greater than other volumes (Table3).
The present results are in agreement with those reported by Ivanov et al., (2013) who developed simple methods for comparing the performance of different types of wastewaters and investigated the highest volumes of $\mathrm{Bio}-\mathrm{H}_{2}$ production from domestic wastewater in MECs operated under fed-batch operation mode.

Table 3. The anode chamber $400 \mathrm{ml}$ for $\mathrm{Bio}-\mathrm{H}_{2}\left(\mathrm{~cm}^{3}\right)$ production with power supply $(0.4 \mathrm{~V}, 0.6 \mathrm{~V}$ and $0.8 \mathrm{~V})$ in MECs from domestic wastewater without bacterial addition.

\begin{tabular}{|c|c|c|c|c|c|c|c|}
\hline \multirow[b]{2}{*}{ Days } & \multirow{2}{*}{$\begin{array}{l}\text { Power } \\
\text { supply }\end{array}$} & \multicolumn{2}{|c|}{$0.4 \mathrm{~V}$} & \multicolumn{2}{|c|}{$0.6 \mathrm{~V}$} & \multicolumn{2}{|c|}{$0.8 \mathrm{~V}$} \\
\hline & & $\begin{array}{c}\text { Burette reading } \\
(\mathrm{cm})\end{array}$ & $\begin{array}{l}\text { Volume of Bio- } \mathrm{H}_{2} \\
\text { collected }\left(\mathrm{cm}^{3}\right)\end{array}$ & $\begin{array}{c}\text { Burette reading } \\
(\mathrm{cm})\end{array}$ & $\begin{array}{c}\text { Volume of Bio- } \mathrm{H}_{2} \\
\text { collected }\left(\mathrm{cm}^{3}\right)\end{array}$ & $\begin{array}{c}\text { Burette reading } \\
(\mathrm{cm})\end{array}$ & $\begin{array}{c}\text { Volume of Bio-H } \\
\text { collected }\left(\mathrm{cm}^{3}\right)\end{array}$ \\
\hline 1 & & 0 & 0.0 & 0 & 0.0 & 0 & 0.0 \\
\hline 2 & & 0 & 0.0 & 0 & 0.0 & 0 & 0.0 \\
\hline 3 & & 0 & 0.0 & 0 & 0.0 & 0 & 0.0 \\
\hline 4 & & 0 & 0.0 & 1.9 & 9.61 & 2.2 & 11.13 \\
\hline 5 & & 1.7 & 8.6 & 3.5 & 17.71 & 4.1 & 20.74 \\
\hline 6 & & 3.4 & 17.2 & 5.4 & 27.32 & 5.9 & 29.85 \\
\hline 7 & & 5.2 & 26.31 & 7.3 & 36.93 & 7.5 & 37.95 \\
\hline 8 & & 6.8 & 34.4 & 8.9 & 45.03 & 9.2 & 46.55 \\
\hline 9 & & 8.4 & 42.5 & 11.1 & 56.16 & 10.9 & 55.15 \\
\hline 10 & & 10.2 & 51.61 & 12.5 & 63.25 & 12.7 & 64.26 \\
\hline 11 & & 11.8 & 59.7 & 14.3 & 72.35 & 14.4 & 72.86 \\
\hline 12 & & 13.4 & 67.8 & 15.9 & 80.45 & 15.8 & 79.94 \\
\hline 13 & & 14.2 & 71.85 & 16.7 & 84.5 & 17 & 86.02 \\
\hline 14 & & 14.6 & 73.87 & 17.1 & 86.52 & 17.6 & 89.05 \\
\hline 15 & & 14.8 & 74.88 & 17.2 & 87.03 & 17.9 & 90.57 \\
\hline $\mathrm{VH}_{2}$ & & 74. & & & $\begin{array}{l}.03 \\
84\end{array}$ & & .57 \\
\hline
\end{tabular}


Hydrogen gas was started production from fourth day with all power supply at anode chamber $500 \mathrm{ml}$, the highest volume of $\mathrm{Bio}-\mathrm{H}_{2} 112.83 \mathrm{~cm}^{3}$ with power supply $0.8 \mathrm{~V}$, which significant differences was found between this volume and other volumes. No significant differences were found between volume of $\mathrm{Bio}-\mathrm{H}_{2}$ $98.16 \mathrm{~cm}^{3}$ with power supply $0.6 \mathrm{~V}$ and the lowest volume of $\mathrm{Bio}_{2} \mathrm{H}_{2} 95.12 \mathrm{~cm}^{3}$ (Table4). The biohydrogen production from domestic wastewater in
MECs at the anode chamber $300 \mathrm{ml}, 400 \mathrm{ml}$ and $500 \mathrm{ml}$ which indicates increasing the domestic wastewater degradation rat. From the thirteenth day the volume of bio-hydrogen started decreasing and stopped from fifteenth day.

The present results are in agreement with those reported by Ditzig et al., (2007) who investigated the bio-hydrogen can be produced from domestic wastewater using MECs as bio-electrochemical reactors.

Table 4. The anode chamber $500 \mathrm{ml}$ for $\mathrm{Bio}-\mathrm{H}_{2}\left(\mathrm{~cm}^{3}\right)$ production with power supply $(0.4 \mathrm{~V}, 0.6 \mathrm{~V}$ and $0.8 \mathrm{~V})$ in MECs from domestic wastewater without bacterial addition.

\begin{tabular}{|c|c|c|c|c|c|c|c|}
\hline \multirow[b]{2}{*}{ Days } & \multirow{2}{*}{$\begin{array}{l}\text { Power } \\
\text { supply }\end{array}$} & \multicolumn{2}{|r|}{$0.4 \mathrm{~V}$} & \multicolumn{2}{|c|}{$0.6 \mathrm{~V}$} & \multicolumn{2}{|r|}{$0.8 \mathrm{~V}$} \\
\hline & & $\begin{array}{c}\text { Burette } \\
\text { reading }(\mathrm{cm})\end{array}$ & $\begin{array}{l}\text { Volume of Bio-H } \\
\text { collected }\left(\mathrm{cm}^{3}\right)\end{array}$ & $\begin{array}{c}\text { Burette reading } \\
\text { (cm) }\end{array}$ & $\begin{array}{c}\text { Volume of } \mathrm{Bio}-\mathrm{H}_{2} \\
\text { collected }\left(\mathrm{cm}^{3}\right)\end{array}$ & $\begin{array}{c}\text { Burette } \\
\text { reading }(\mathrm{cm})\end{array}$ & $\begin{array}{l}\text { Volume of Bio-H } \\
\text { collected }\left(\mathrm{cm}^{3}\right)\end{array}$ \\
\hline 1 & & 0 & 0.0 & 0 & 0.0 & 0 & 0.0 \\
\hline 2 & & 0 & 0.0 & 0 & 0.0 & 0 & 0.0 \\
\hline 3 & & 0 & 0.0 & 0 & 0.0 & 0 & 0.0 \\
\hline 4 & & 1.5 & 7.59 & 1.8 & 9.1 & 2.4 & 12.14 \\
\hline 5 & & 3.7 & 18.72 & 4.1 & 20.74 & 4.8 & 24.28 \\
\hline 6 & & 5.9 & 29.85 & 6.3 & 31.87 & 7.2 & 35.92 \\
\hline 7 & & 8.4 & 42.5 & 8.9 & 45.03 & 9.6 & 48.57 \\
\hline 8 & & 10.2 & 51.61 & 11 & 55.66 & 12 & 60.72 \\
\hline 9 & & 12 & 60.72 & 13.4 & 67.8 & 14.5 & 73.37 \\
\hline 10 & & 13.6 & 68.81 & 15 & 75.9 & 17.1 & 86.52 \\
\hline 11 & & 15.2 & 76.91 & 16.6 & 83.99 & 18.8 & 95.12 \\
\hline 12 & & 16.8 & 85 & 17.8 & 90.06 & 20.1 & 101.7 \\
\hline 13 & & 18 & 91.08 & 18.9 & 95.63 & 21.7 & 109.8 \\
\hline 14 & & 18.6 & 94.11 & 19.3 & 97.65 & 22.1 & 111.82 \\
\hline 15 & & 18.8 & 95.12 & 19.4 & 98.16 & 22.3 & 112.83 \\
\hline $\begin{array}{l}\mathrm{VH}_{2} \\
\mathrm{LSD}\end{array}$ & & & 95.12 & $\begin{array}{l}89 \\
4.4\end{array}$ & 42 & & 12.83 \\
\hline
\end{tabular}

Bio-hydrogen Production from domestic wastewater by Enterobacter aerogenes DSM 30053:

$30 \mathrm{ml}, 40 \mathrm{ml}$ and $50 \mathrm{ml}$ of bacterial culture of Enterobacter aerogenes DSM 30053 and $300 \mathrm{ml}, 400$ $\mathrm{ml}$ and $500 \mathrm{ml}$ of domestic wastewater were added to anode chamber in MECs respectively and $300 \mathrm{ml}, 400$ $\mathrm{ml}$ and $500 \mathrm{ml}$ of distilled water were added to cathode chamber. Fourth day with power supply $0.4 \mathrm{~V}$ and 0.6 $\mathrm{V}$ in MECs at the anode chamber $300 \mathrm{ml}$ of domestic wastewater and fifth day with power supply $0.8 \mathrm{~V}$, the hydrogen gas can be produced. Significant differences were found between the highest volume of $\mathrm{Bio}-\mathrm{H}_{2}$ $138.13 \mathrm{~cm}^{3}$ with power supply $0.4 \mathrm{~V}$ and other volumes of Bio- $\mathrm{H}_{2}$ with power supply $0.6 \mathrm{~V}$ and $0.8 \mathrm{~V}$. While the lowest volume of $\mathrm{Bio}-\mathrm{H}_{2} 80.45 \mathrm{~cm}^{3}$ with power supply $0.8 \mathrm{~V}$. (Table 5).

These results are confirm with Lu et al., ( 2012 ) they also used Enterobacter aerogenes for biohydrogen production from glucose as substrate in microbial electrolysis cells at low temperature.

Table 5. The anode chamber $300 \mathrm{ml}$ for Bio- $\mathrm{H}_{2}\left(\mathrm{~cm}^{3}\right)$ production with power supply $(0.4 \mathrm{~V}, 0.6 \mathrm{~V}$ and $0.8 \mathrm{~V})$ in MECs from domestic wastewater by Enterobacter aerogenes DSM 30053.

\begin{tabular}{|c|c|c|c|c|c|c|c|}
\hline \multirow[b]{2}{*}{ Days } & \multirow{2}{*}{$\begin{array}{l}\text { Power } \\
\text { supply }\end{array}$} & \multicolumn{2}{|c|}{$0.4 \mathrm{~V}$} & \multicolumn{2}{|c|}{$0.6 \mathrm{~V}$} & \multicolumn{2}{|c|}{$0.8 \mathrm{~V}$} \\
\hline & & $\begin{array}{c}\text { Burette } \\
\text { reading }(\mathrm{cm})\end{array}$ & $\begin{array}{l}\text { Volume of Bio-H } \\
\text { collected }\left(\mathrm{cm}^{3}\right)\end{array}$ & $\begin{array}{c}\text { Burette } \\
\text { reading }(\mathrm{cm})\end{array}$ & $\begin{array}{l}\text { Volume of Bio-H } \\
\text { collected }\left(\mathrm{cm}^{3}\right)\end{array}$ & $\begin{array}{c}\text { Burette } \\
\text { reading }(\mathrm{cm})\end{array}$ & $\begin{array}{l}\text { Volume of Bio-H } \\
\text { collected }\left(\mathrm{cm}^{3}\right)\end{array}$ \\
\hline 1 & & 0 & 0.0 & 0 & 0.0 & 0 & 0.0 \\
\hline 2 & & 0 & 0.0 & 0 & 0.0 & 0 & 0.0 \\
\hline 3 & & 0 & 0.0 & 0 & 0.0 & 0 & 0.0 \\
\hline 4 & & 2.5 & 12.65 & 1.6 & 8.09 & 0 & 0.0 \\
\hline 5 & & 6.7 & 33.9 & 2.9 & 14.67 & 1.2 & 6.07 \\
\hline 6 & & 9.5 & 48.07 & 5.4 & 27.32 & 2.8 & 14.16 \\
\hline 7 & & 12.8 & 64.67 & 7.7 & 38.57 & 5.5 & 27.83 \\
\hline 8 & & 16.6 & 83.99 & 9.6 & 48.57 & 8.1 & 40.98 \\
\hline 9 & & 20.2 & 102.21 & 12.8 & 64.76 & 10.5 & 53.13 \\
\hline 10 & & 23.2 & 117.39 & 15.6 & 78.93 & 12.7 & 64.26 \\
\hline 11 & & 25 & 126.5 & 17.4 & 88.04 & 13.9 & 70.33 \\
\hline 12 & & 26.2 & 132.57 & 19 & 96.14 & 14.8 & 74.88 \\
\hline 13 & & 26.8 & 135.6 & 19.8 & 100.18 & 15.3 & 77.41 \\
\hline 14 & & 27.1 & 137.12 & 21.2 & 107.27 & 15.7 & 79.44 \\
\hline 15 & & 27.3 & 138.13 & 21.4 & 108.28 & 15.9 & 80.45 \\
\hline $\begin{array}{l}\mathrm{VH}_{2} \\
\mathrm{LSD}\end{array}$ & & & 38.13 & & $\begin{array}{l}08.28 \\
5.76\end{array}$ & & 80.45 \\
\hline
\end{tabular}


In MEC the hydrogen gas production in cathode chamber started from second day with power supply 0.4 $\mathrm{V}$ and third day with power supply $0.6 \mathrm{~V}$ and $0.8 \mathrm{~V}$ onwards till fifteenth day at the anode chamber $400 \mathrm{ml}$. Significant differences were found between the highest volume of Bio- $\mathrm{H}_{2} 211.5 \mathrm{~cm}^{3}$ with power supply $0.4 \mathrm{~V}$ and lowest volume of Bio- $\mathrm{H}_{2} 149.77 \mathrm{~cm}^{3}$ with power supply $0.8 \mathrm{~V}$. ( Table 6 ).These results are in agreement with Kiran and Gaur ( 2013 ) found that Enterobacter aerogenes able to degradation of organic matter in a variable substrates and electron transfer from anode to cathode electrodes in microbial fuel cell for electricity generation and bio-hydrogen production.

Table 6. The anode chamber $400 \mathrm{ml}$ for $\mathrm{Bio}-\mathrm{H}_{2}\left(\mathrm{~cm}^{3}\right)$ production with power supply $(0.4 \mathrm{~V}, 0.6 \mathrm{~V}$ and $0.8 \mathrm{~V})$ in MECs from domestic wastewater by Enterobacter aerogenes DSM 30053.

\begin{tabular}{|c|c|c|c|c|c|c|}
\hline \multirow[b]{2}{*}{ Days } & \multicolumn{2}{|l|}{ Power } & \multicolumn{2}{|c|}{$0.6 \mathrm{~V}$} & \multicolumn{2}{|c|}{$0.8 \mathrm{~V}$} \\
\hline & $\begin{array}{c}\text { supply Burette reading } \\
(\mathrm{cm})\end{array}$ & $\begin{array}{l}\text { Volume of Bio- } \mathrm{H}_{2} \\
\text { collected }\left(\mathrm{cm}^{3}\right)\end{array}$ & $\begin{array}{c}\text { Burette reading } \\
(\mathrm{cm})\end{array}$ & $\begin{array}{l}\text { Volume of } \mathrm{Bio}-\mathrm{H}_{2} \\
\text { collected }\left(\mathrm{cm}^{3}\right)\end{array}$ & $\begin{array}{c}\text { Burette reading } \\
(\mathrm{cm})\end{array}$ & $\begin{array}{l}\text { Volume of Bio-H } \\
\text { collected }\left(\mathrm{cm}^{3}\right)\end{array}$ \\
\hline$\overline{1}$ & 0 & 0.0 & 0 & 0.0 & 0 & 0.0 \\
\hline 2 & 2.2 & 11.13 & 0 & 0.0 & 0 & 0.0 \\
\hline 3 & 5.8 & 29.34 & 2.4 & 12.14 & 1.9 & 9.6 \\
\hline 4 & 9.6 & 48.57 & 6.8 & 34.4 & 5.4 & 27.32 \\
\hline 5 & 13.5 & 68.31 & 11 & 55.66 & 8.7 & 44.02 \\
\hline 6 & 18 & 91.08 & 15.1 & 76.4 & 11.5 & 58.19 \\
\hline 7 & 24.4 & 123.46 & 18.8 & 95.12 & 14.9 & 75.39 \\
\hline 8 & 29.1 & 147.24 & 22.4 & 113.34 & 18.5 & 93.61 \\
\hline 9 & 32.5 & 164.45 & 25.8 & 130.54 & 21.9 & 110.81 \\
\hline 10 & 35.7 & 180.64 & 29 & 146.74 & 24.3 & 122.95 \\
\hline 11 & 37.5 & 189.75 & 31.5 & 159.39 & 26.8 & 135.6 \\
\hline 12 & 39.7 & 200.88 & 33.8 & 171.02 & 28.4 & 143.7 \\
\hline 13 & 40.9 & 206.95 & 35.7 & 177.6 & 29.1 & 147.24 \\
\hline 14 & 41.5 & 209.99 & 35.9 & 180.64 & 29.5 & 149.27 \\
\hline 15 & 41.8 & 211.5 & 36.2 & 181.65 & 29.6 & 149.77 \\
\hline $\begin{array}{l}\mathrm{VH}_{2} \\
\mathrm{LSD}_{\mathrm{c}}\end{array}$ & 21 & & & & & \\
\hline
\end{tabular}

Table 7 presents the volumes of bio-hydrogen production in MECs at the anode chamber $500 \mathrm{ml}$ with power supply $0.4 \mathrm{~V}, 0.6 \mathrm{~V}$ and $0.8 \mathrm{~V}$. The hydrogen gas was started production from second day with power supply $0.4 \mathrm{~V}$ and third day with power supply $0.6 \mathrm{~V}$ and $0.8 \mathrm{~V}$. The highest volume of Bio- $\mathrm{H}_{2} 316.25 \mathrm{~cm}^{3}$ with power supply $0.4 \mathrm{~V}$, which were significant differences found between this volume and other volumes. The lowest volume of Bio- $\mathrm{H}_{2} 225.67 \mathrm{~cm}^{3}$ was obtained with power supply $0.8 \mathrm{~V}$. These results are confirm with Wang et al., (2015) found that highest hydrogen yield and volume of bio-hydrogen were obtained with low power supply using molasses wastewater as substrate in MECs.

Table7. The anode chamber $500 \mathrm{ml}$ for $\mathrm{Bio}-\mathrm{H}_{2}\left(\mathrm{~cm}^{3}\right)$ production with power supply $(0.4 \mathrm{~V}, 0.6 \mathrm{~V}$ and $0.8 \mathrm{~V})$ in MECs from domestic wastewater by Enterobacter aerogenes DSM 30053.

\begin{tabular}{|c|c|c|c|c|c|c|c|}
\hline \multirow[b]{2}{*}{ Days } & \multicolumn{3}{|l|}{ Power } & \multicolumn{2}{|c|}{$0.6 \mathrm{~V}$} & \multicolumn{2}{|c|}{$0.8 \mathrm{~V}$} \\
\hline & supply & $\begin{array}{c}\text { Burette reading } \\
(\mathrm{cm})\end{array}$ & $\begin{array}{c}\text { Volume of Bio-H } \\
\text { collected }\left(\mathrm{cm}^{3}\right)\end{array}$ & $\begin{array}{c}\text { Burette reading } \\
(\mathrm{cm})\end{array}$ & $\begin{array}{c}\text { Volume of Bio- } \mathrm{H}_{2} \\
\text { collected }\left(\mathrm{cm}^{3}\right)\end{array}$ & $\begin{array}{c}\text { Burette reading } \\
(\mathrm{cm})\end{array}$ & $\begin{array}{c}\text { Volume of Bio- } \mathrm{H}_{2} \\
\text { collected }\left(\mathrm{cm}^{3}\right)\end{array}$ \\
\hline 1 & & 0 & 0.0 & 0 & 0.0 & 0 & 0.0 \\
\hline 2 & & 2.8 & 14.16 & 0 & 0.0 & 0 & 0.0 \\
\hline 3 & & 5.6 & 28.33 & 2.5 & 12.65 & 2.3 & 11.63 \\
\hline 4 & & 10.5 & 53.13 & 6.2 & 31.37 & 5.9 & 29.85 \\
\hline 5 & & 16.4 & 82.98 & 10.6 & 53.63 & 9.7 & 49.08 \\
\hline 6 & & 23.8 & 120.42 & 14 & 70.84 & 13.8 & 69.82 \\
\hline 7 & & 29.3 & 148.42 & 19.3 & 97.65 & 18.4 & 93.1 \\
\hline 8 & & 35.6 & 180.13 & 25.3 & 128.01 & 23.6 & 119.41 \\
\hline 9 & & 41.4 & 209.48 & 31.7 & 160.4 & 27.2 & 137.63 \\
\hline 10 & & 47.2 & 238.83 & 35.4 & 179.12 & 32 & 161.92 \\
\hline 11 & & 53.6 & 270.2 & 38.6 & 192.28 & 35.9 & 178.11 \\
\hline 12 & & 58.6 & 296.51 & 42.2 & 213.53 & 43.5 & 201.89 \\
\hline 13 & & 60.5 & 306.13 & 44.5 & 225.17 & 43.5 & 220.11 \\
\hline 14 & & 61.9 & 313.21 & 45.8 & 230.23 & 44.3 & 224.15 \\
\hline 15 & & 62.5 & 316.25 & 46.3 & 234.27 & 44.6 & 225.67 \\
\hline $\begin{array}{l}\overline{\mathrm{VH}} \mathrm{H}_{2} \text { at5\% }\end{array}$ & & 316 & 5.25 & $\begin{array}{r}234 \\
6 .\end{array}$ & $\begin{array}{l}4.27 \\
45\end{array}$ & 22 & 5.67 \\
\hline
\end{tabular}

Production of Bio- $\mathrm{H}_{2}$ Without and with Bacteria in MECs:

Evaluation of volume of $\mathrm{Bio}-\mathrm{H}_{2}$ production from domestic wastewater in the experiments with and without addition of bacteria while keeping all other condition the same. The highest volume of Bio- $\mathrm{H}_{2} 316$ $\mathrm{cm}^{3}$ production by Enterobacter aerogenes DSM 30053 at the anode chamber $500 \mathrm{ml}$ with power supply $0.4 \mathrm{~V}$.
While the highest volume of Bio- $\mathrm{H}_{2}$ production without addition of bacteria at the same chamber with power supply $0.8 \mathrm{~V} 112.83 \mathrm{~cm}^{3}$, which revealed significant positive relationship were found between the volume of Bio- $\mathrm{H}_{2}$ production and addition of bacteria in MECs. But significant negative relationship increasing with power supply. The volume of $\mathrm{Bio}-\mathrm{H}_{2}$ production from domestic wastewater in MECs with and without 
addition of bacteria shown in Table (8). It is evident that the volume of $\mathrm{Bio}-\mathrm{H}_{2}$ evolved are more than doubled as an effect of adding bacteria. This results are agreement with Afify et al., (2017) reported that the Bio- $\mathrm{H} 2$ production in MECs increased from second and third day till thirteenth day when inoculation with enteric bacteria (E. coli NRRL B-3008) which increasing the substrate degradation rate.

Table 8. Comparison of $\mathrm{Bio}-\mathrm{H}_{2}\left(\mathrm{~cm}^{3}\right)$ production in MECs without and with addition Enterobacter aerogenes DSM 30053 from domestic wastewater.

\begin{tabular}{lccc}
\hline \multirow{2}{*}{ MECs } & $\begin{array}{c}\text { Power } \\
\text { supply } \\
\end{array}$ & $\begin{array}{c}\text { Without } \\
\text { bacteria }\end{array}$ & $\begin{array}{c}\text { Enterobacter } \\
\text { aerogenes DSM 30053 }\end{array}$ \\
\cline { 3 - 4 } $\mathbf{V H}_{\mathbf{2}}\left(\mathbf{c m}^{\mathbf{3}}\right)$ & $\mathbf{V H}_{\mathbf{2}} \mathbf{( \mathbf { c m } ^ { 3 } )}$ \\
\hline Anode & $0.4 \mathrm{~V}$ & 41.49 & 138.13 \\
chamber & $0.6 \mathrm{~V}$ & 52.11 & 108.28 \\
$300 \mathrm{ml}$ & $0.8 \mathrm{~V}$ & 54.64 & 80.45 \\
Anode & $0.4 \mathrm{~V}$ & 74.88 & 211.5 \\
chamber & $0.6 \mathrm{~V}$ & 87.03 & 181.65 \\
400 ml & $0.8 \mathrm{~V}$ & 90.57 & 149.77 \\
Anode & $0.4 \mathrm{~V}$ & 95.12 & 316 \\
chamber & $0.6 \mathrm{~V}$ & 98.16 & 234.27 \\
500 ml & $0.8 \mathrm{~V}$ & 112.83 & 225.67 \\
\hline LSD at 5\% & & 7.92 & 16.13 \\
\hline
\end{tabular}

\section{REFERENCES}

Abd El Rahman, N.K. (2017).Studies on production of bio-hydrogen from bacteria. $\mathrm{Ph}$. D. Thesis, Fac. Of Agric. Mans. Univ. pp.169.

Afify, Aida, H.; M. M. Kassem ; A. M. Abd EL Gwad and N. K. Abd EL Rahman (2017). Biohydrogen Production By Escherichia coli NRRL B-3008 and Pseudomonas aeruginosa ATCC 27853 Using Microbial Electrolysis Cells. J. Agric. Chem. and Biotechn., Mansoura Univ. Vol. 8(2): $63-68$.
Ditzig, J.; H. Liu and B. E. Logan (2007). Production of Hydrogen from Domestic Wastewater Using a Bio-electrochemically Assisted Microbial Reactor (BEAMR). Int. J. of Hydrogen Energy Vol. (32) :2296-2599.

Ivanov, I.; L. J. Ren; M. Siegert and B. E. Logan (2013). a Quantitative Method to Evaluate Microbial Electrolysis Cell Effectiveness for Energy Recovery and Wastewater Treatment. Int. J. Hydrogen Energy Vol. (30):13135-13176.

Jia Y. H.; J. Y. Choi ; J. H. Ryu ; C. H. Kim ; W. K. Lee ; H. T. Tran ; R. H. Zhang and D. H. Ahn (2010). Hydrogen production from wastewater using a microbial electrolysis cell. Korean J. Chem. Eng. Vol. 27 (6): 1854-1859.

Kiran, V. and B. Gaur (2013). Microbial Fuel Cell: Technology for Harvesting Energy from Biomass. Rev. Chem. Eng. Vol.(29) :189-203.

Lu, L.; D. Xing; N. Ren and B. E. Logan (2012). Syntrophic Interactions Drive the Hydrogen Production from Glucose at Low Temperature in Microbial Electrolysis Cells Bioreso. Techno. Vol. (124): 68-76.

Montpart N.; L. Rago ; J. A. Baeza and A. Guisasola (2015). Hydrogen production in single chamber microbial electrolysis cells with different complex substrates. Water Res. 68: 601- 615.

Ujwal S. M.; M. A. Rakesh and L. A. Raj ( 2015 ). Biohydrogen production in microbial electrolysis cell using waste water from sugar industry. Int. J. of Engineering Sci. \& Res. Technol. Vol. 4 (4) : 452-458.

Wang, Y.; W. Q. Guo; D. F. Xing; J. S. Chang and M. Q. Ren (2015). Hydrogen Production Using Biocathode Single-Chamber Microbial Electrolysis Cells Fed by Molasses Wastewater at Low Temperature. Int. J. Hydrogen Energy Vol. (33): 19369-19443.

\footnotetext{
إستخدام بكتيريا الـ Enterobacter aerogenes DSM 30053 لإنتاج الهيدروجين الحيوى بواسطة خلايـ

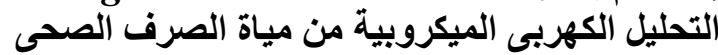

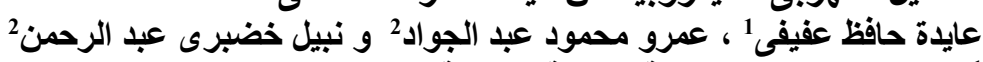

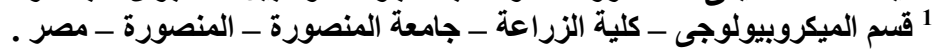

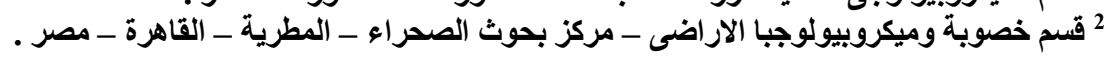

تهـف هذه الدر اسـة إلى استخدام خلايـا التحليل الكهربـى الميكروبيـة لإنتـاج الهيدروجين الحيوى بواسطة ميكروب إنتروبـاكتر

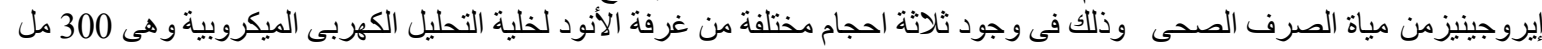

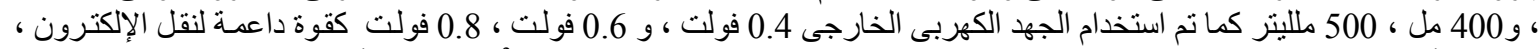

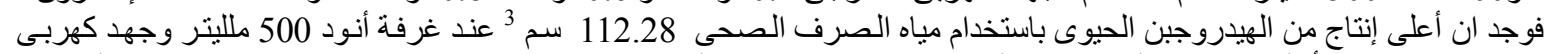

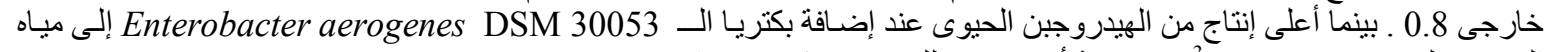

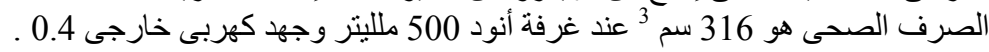

